Original Research Paper

\title{
Callus Induction from Cotyledon of Gyrinops versteegii (Gilg.) Domke
}

\author{
Fajri Marisa, Lisna Hidayati, Aries Bagus Sasongko, Tri Rini Nuringtyas* \\ Fakultas Biologi, Universitas Gadjah Mada, Yogyakarta, Indonesia
}

\author{
Article History \\ Received : May $03^{\text {th }}, 2021$ \\ Revised : May $12^{\text {th }}, 2021$ \\ Accepted : May $28^{\text {th }}, 2021$ \\ Published : June $07^{\text {th }}, 2021$ \\ *Corresponding Author: \\ Tri Rini Nuringtyas, \\ Fakultas Biologi \\ Universitas Gadjah Mada \\ Yogyakatya, Indonesia; \\ Email: tririni@ugm.ac.id
}

\begin{abstract}
Gyrinops versteegii is an endemic plant in eastern Indonesia that produced agarwood with high quality and economic value. This plant has been threatened by overexploitation which leads on decreasing in the natural population. This research aimed to induce in vitro callus formation to support the sustainable utilization of G. versteegii, which in the end, may support plant productivity. Callus induction was investigated using cotyledon and cultured on MS medium supplemented with several combination of plant growth regulators. The observations were done for the number of explants turned into callus and the duration for the first callus formation. The results showed that combination of 3 $\mathrm{mg} / \mathrm{L} \mathrm{NAA}+0.5 \mathrm{mg} / \mathrm{L} \mathrm{BAP}$ was recorded as the best combination for callus induction $(63.63 \%)$. Callus with friable structure and bright color are obtained within nine days of incubation and showed the characteristic of embryonic callus. This result is expected to give a significant opportunity to conserve the natural population of $G$. versteegii.
\end{abstract}

Keywords: Gyrnops versteegii; callus; in vitro; plant growth regulator.

\section{Pendahuluan}

Gyrinops verteegii (Gilg.) Domke merupakan salah satu spesies penghasil gaharu endemik Indonesia dengan kualitas tinggi. Resin dari tanaman ini memiliki harga jual sangat tinggi (Susilo et al., 2014). Spesies ini secara alami terdistribusi di bagian timur Indonesia seperti Nusa Tenggara Timur (NTT), Lombok, Sulawesi dan Papua (Trimulyanigsih, 2014).

Berdasarkan Peraturan Pemerintah No. 7/1999 dan Permenhut No. 447/Kpts-II/2003 menetapkan bahwa $G$. versteegii sebagai salah satu jenis tanaman penghasil gaharu yang dilindungi dan dilarang untuk ditebang (Susilo et al., 2014). CITES (The Convention on International Trade in Endangered Species of Wild Flora dan Fauna) juga mengelompokan status konservasi G. versteegii ke dalam daftar appendix II. Padahal penelitian mengenai $G$. versteegii semakin banyak dilakukan dan didukung oleh kemampuan bioaktivitasnya sebagai antioksidan (Nuringtyas et al., 2018), antikanker (Nuringtyas et al., 2018; Wardana et al., 2019) dan antivirus (Masita et al., 2020).
Oleh karena itu, perlu dilakukan pengontrolan terhadap perdagangan spesies ini (Aini, 2015). Sebagai langkah antisipatif, diperlukan suatu usaha budidaya alternatif yang dapat menunjang kelestarian gaharu spesies ini.

Kultur in vitro merupakan salah satu teknik mikropropagasi yang dapat digunakan untuk budidaya secara masal dan cepat (Benjamin et al., 2019). Salah satu teknik dalam kultur in vitro yang sering digunakan untuk mikropropagasi adalah induksi kalus yang mampu menghasilkan sel-sel yang bersifat meristematik (Efferth, 2019). Adapun protokol yang secara efisien mampu menginduksi kalus dengan zat pengatur tumbuh (ZPT) pada spesies Gyrinops walla dan Aquilaria malaccensis telah dilaporkan oleh Munasinghe et al., (2017) dan Saikia et al., (2013) dengan menggunakan eksplan daun. Hanya saja, pertumbuhan dan perkembangan kalus yang diperoleh dilaporkan masih sangat lambat. Oleh karena itu diperlukan penelitian untuk mencoba penggunaan sumber eksplan yang berbeda.

Berbagai penelitian melaporkan bahwa kotiledon adalah eksplan yang memiliki 
produktifitas tinggi (Raza et al., 2019), sehingga sangat berpotensi digunakan sebagai eksplan kultur mikropropagasi dengan tujuan produksi secara masal dan konservasi. Studi yang mengkaji induksi kalus berasal dari kotiledon $G$. versteegii belum pernah dilakukan.

\section{Bahan dan Metode}

\section{Pembuatan Medium Induksi Kalus}

Medium yang digunakan adalah Murashige and Skoog (MS) padat yang diperoleh dengan menambahkan agar sebanyak $0,7 \%$. Kombinasi ZPT dilakukan dengan dua variasi yaitu kombinasi A: kinetin (KIN) + 2,4D dan kombinasi B: BAP + NAA seperti yang ditampilkan pada Tabel 1.

Sebanyak masing-masing $1 \mathrm{~L}$ medium dihomogenkan kemudian $\mathrm{pH}$ diatur pada kisaran antara 5,8 sampai 6,2. Selanjutnya, sebanyak masing-masing $20 \mathrm{~mL}$ medium dituang ke dalam botol kultur, dan disterilisasi menggunakan autoklaf pada suhu $121^{\circ} \mathrm{C}$ dengan tekanan $1 \mathrm{~atm}$ selama 20 menit. Setelah sterilisasi selesai, medium dalam kondisi masih cair dan hangat dituang ke dalam cawan petri secara aseptis dalam LAF.

Tabel 1. Kombinasi konsentrasi ZPT untuk medium induksi kalus dari kotiliedon $G$. versteegii

\begin{tabular}{cl}
\hline Perlakuan & \multicolumn{1}{c}{ Konsentrasi ZPT } \\
\hline A1 & $0,05 \mathrm{mg} / \mathrm{L} \mathrm{KIN}+1 \mathrm{mg} / \mathrm{L} 2,4 \mathrm{D}$ \\
$\mathrm{A} 2$ & $0,1 \mathrm{mg} / \mathrm{L} \mathrm{KIN}+2 \mathrm{mg} / \mathrm{L} 2,4 \mathrm{D}$ \\
$\mathrm{A} 3$ & $0,15 \mathrm{mg} / \mathrm{L} \mathrm{KIN}+3 \mathrm{mg} / \mathrm{L} 2,4 \mathrm{D}$ \\
$\mathrm{B} 1$ & $0,25 \mathrm{mg} / \mathrm{L} \mathrm{BAP}+1 \mathrm{mg} / \mathrm{L} \mathrm{NAA}$ \\
$\mathrm{B} 2$ & $0,5 \mathrm{mg} / \mathrm{L} \mathrm{BAP}+3 \mathrm{mg} / \mathrm{L} \mathrm{NAA}$ \\
$\mathrm{B} 3$ & $1 \mathrm{mg} / \mathrm{L} \mathrm{BAP}+5 \mathrm{mg} / \mathrm{L} \mathrm{NAA}$ \\
\hline
\end{tabular}

\section{Preparasi Eksplan}

Biji tanaman G. versteegii diperoleh dari perkebunan gaharu di wilayah Klaten, Jawa Tengah. Biji disterilisasi menggunakan $10 \%$ larutan natrium hipoklorit (Bayclean) yang ditambah dengan 3 tetes Tween 20 selama 5 menit. Selanjutnya dilakukan penggojokkan dalam alkohol $70 \%$ selama 1 menit, dan terakhir biji dibilas menggunakan akuades steril sebanyak 3 kali. Biji yang telah steril kemudian dikecambahkan dalam medium $\frac{1}{2}$ MS selama 2 bulan.

Kotiledon dikoleksi dari kecambah $G$. versteegii yang telah berukuran $2 \mathrm{~cm}$. Tiap kotiledon dipotong pada bagian dasarnya kemudian dibagi menjadi 2 bagian dengan ukuran yang sama. Seluruh aktivitas kultur dilakukan secara aseptis dalam LAF

\section{Induksi Pembentukan Kalus}

Tiap eksplan kotiledon dikultur ke dalam medium induksi kalus yaitu A1, A2, A3, B1, B2, dan B3 (Tabel 1). Tiap petri berisi 3 potong kotiledon, kemudian diinkubasi dengan kondisi tanpa cahaya (gelap total) dengan suhu ruang berkisar $25^{\circ} \mathrm{C}$.

\section{Pengamatan Kalus}

Pengamatan pembentukan kalus dilakukan pada siang hari dan diulangi setiap 3 hari sekali selama 42 hari. Karakter yang diamati antara lain adalah kemunculan kalus pertama, warna, tekstur, dan ukuran kalus.

\section{Analisis data}

Data yang diperoleh dianalisis dengan menghitung persentasi keberhasilan pembentukan kalus dan ukuran luas kalus yang dihasilkan.

Persentasi keberhasilan kalus dihitung dengan rumus:

Persen keberhasilan $=\frac{\text { Banyak eksplan berkalus }}{\text { Total eksplan }} \times 100 \%$

Ukuran luas kalus dihitung dengan menggunakan aplikasi KLONK image measurement. Data luas kalus yang diperoleh dianalisis menggunakan One-Way ANOVA pada tingkat signifikansi $p<$ 0,05 . Hasil yang signifikan dilanjutkan dengan analisis post hoc Duncan.

\section{Hasil dan Pembahasan}

\section{Keberhasilan Induksi Kalus}

Penelitian induksi kalus dengan sumber eksplan dari kotiledon G. versteegii dilakukan dengan menggunakan berbagai kombinasi dan konsentrasi ZPT dalam medium perlakuan yaitu $\mathrm{A} 1, \mathrm{~A} 2, \mathrm{~A} 3, \mathrm{~B} 1, \mathrm{~B} 2$, dan $\mathrm{B} 3$ dengan rincian kombinasi seperti pada Tabel 1. Hasil penelitian menunjukkan bahwa semua perlakuan kombinasi ZPT berhasil menginduksi pembentukan kalus 
(Tabel 2). Induksi kalus kotiledon G. versteegii memberikan rata-rata waktu pembentukan kalus paling cepat selama 6 hari yang diperoleh pada medium dengan kombinasi ZPT A2 $(0,1 \mathrm{mg} / \mathrm{L}$ $\mathrm{KIN}+2 \mathrm{mg} / \mathrm{L} 2,4 \mathrm{D}) . \mathrm{A} 3(0,15 \mathrm{mg} / \mathrm{L} \mathrm{KIN}+3$ $\mathrm{mg} / \mathrm{L} 2,4 \mathrm{D})$ dan B1 $(0,25 \mathrm{mg} / \mathrm{L} \mathrm{BAP}+1 \mathrm{mg} / \mathrm{L}$ NAA) dengan persentasi keberhasilan pembentukkan kalus menengah yaitu $54,54 \%$. Persentase keberhasilan pembentukan kalus tertinggi diperlihatkan pada medium perlakuan dengan kombinasi ZPT B2 $(0,5 \mathrm{mg} / \mathrm{L}$ BAP +3 mg/L NAA) yaitu 63,63\% dengan rata-rata lama pembentukan kalus adalah 9 hari. Medium dengan kombinasi ZPT B2 $(0,5 \mathrm{mg} / \mathrm{L} \mathrm{BAP}+3$ $\mathrm{mg} / \mathrm{L}$ NAA) dan B3 (1 mg/L BAP + $5 \mathrm{mg} / \mathrm{L}$ NAA) menunjukkan hasil seragam, yang mana waktu pembentukan kalusnya berkisar 9 hari (Tabel 2.).

Performa induksi kalus yang berbeda dari yang lain ditunjukkan oleh kombinasi ZPT A1 $(0,05 \mathrm{mg} / \mathrm{L} \mathrm{KIN}+1 \mathrm{mg} / \mathrm{L} 2,4 \mathrm{D})$ yang memiliki persentasi keberhasilan induksi terendah yaitu sebesar $27,27 \%$, dan waktu pembentukan kalus yang paling lama muncul, yaitu 18 hari (Tabel 2.). Eksplan yang dikultur pada medium A1 mengalami pertumbuhan yang sangat lambat, kemungkinan diakibatkan kurangnya ZPT yang diberikan untuk mendukung induksi kalus. Hal ini menunjukkan bahwa konsentrasi dan kombinasi ZPT yang tepat sangat mempengaruhi kecepatan munculnya kalus.

Tabel 2. Pengaruh penambahan berbagai konsentrasi dan kombinasi ZPT terhadap pembentukan kalus kotiledon Girynops versteegii

\begin{tabular}{ccc}
\hline Pelakuan & $\begin{array}{c}\text { Banyak eksplan } \\
\text { berkalus (\%) }\end{array}$ & $\begin{array}{c}\text { Waktu pembentukan } \\
\text { kalus pertama (hari) }\end{array}$ \\
\hline K & 0 & - \\
A1 & 27,27 & 18 \\
A2 & 54,54 & 6 \\
A3 & 54,54 & 6 \\
B1 & 54,54 & 6 \\
B2 & 63,63 & 9 \\
B3 & 54,54 & 9 \\
\hline
\end{tabular}

Ket : $\mathrm{A} 1=1 \mathrm{mg} / \mathrm{L} 2,4 \mathrm{D}+0.05 \mathrm{mg} / \mathrm{L}$ KIN, $\mathrm{A} 2=2$ $\mathrm{mg} / \mathrm{L} 2,4 \mathrm{D}+0.1 \mathrm{mg} / \mathrm{L} \mathrm{KIN}, \mathrm{A} 3=3 \mathrm{mg} / \mathrm{L} 2,4 \mathrm{D}+$ $0.15 \mathrm{mg} / \mathrm{L} \mathrm{KIN}, \mathrm{B} 1=1 \mathrm{mg} / \mathrm{L} \mathrm{NAA}+0.25 \mathrm{mg} / \mathrm{L} \mathrm{BAP}$, $\mathrm{B} 2=3 \mathrm{mg} / \mathrm{L} \mathrm{NAA}+0,5 \mathrm{mg} / \mathrm{L} \mathrm{BAP}, \mathrm{B} 3=5 \mathrm{mg} / \mathrm{L}$ $\mathrm{NAA}+1 \mathrm{mg} / \mathrm{L}$ BAP. $\mathrm{K}=$ Kontrol.

Induksi pembentukkan kalus pada eksplan kotiledon diawali oleh terjadinya pembengkakan pada beberapa titik pada permukaan eksplan yang mengalami perlukaan (Gambar 1.). Penampakan eksplan menjadi membengkak dan ukuran eksplan membesar, hingga akhirnya kalus terbentuk. Menurut Sari et al. (2018), pembengkakan dan pemanjangan yang terjadi pada eksplan berhubungan erat dengan penyerapan nutrisi dari medium oleh eksplan. Sedangkan kemunculan kalus pada bagian yang terluka diakibatkan oleh respon tumbuhan untuk memperbaiki jaringan yang mengalami kerusakan. George dan Sherrington (1984) mengemukakan bahwa hormon endogen yang terkandung dalam eksplan mendukung terjadinya respons jaringan untuk membentuk kalus. Kotiledon merupakan jaringan aktif dan kaya akan hormon pertumbuhan seperti auksin dan sitokinin, sehingga memunginkan induksi kalus berlangsung lebih cepat.

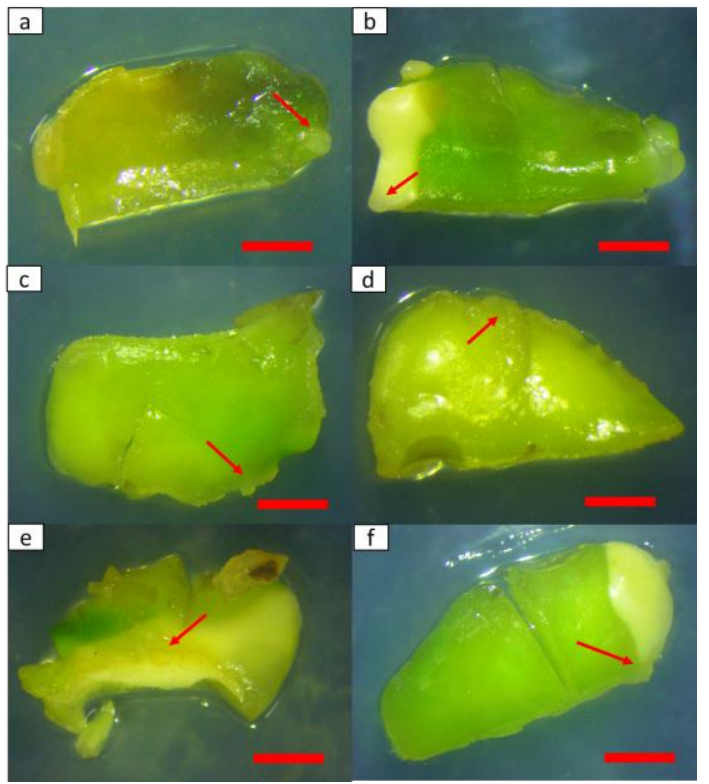

Gambar 1. Penampakan eksplan kotiledon Gyrinops versteegii pada awal kemunculan kalus. a) Perlakuan A1; b) Perlakuan A2; c) Perlakuan A3; d) Perlakuan B1; e) Perlakuan B2; dan f) Perlakuan B3. Tanda panah menunjukkan kalus pertama yang muncul. Bar $=1 \mathrm{~mm}$

\section{Karakter Morofologi Kalus}

Hasil pengamatan morofologi kalus menunjukkan bahwa ukuran kalus terbesar diperlihatkan pada medium perlakuan B2 yaitu sebesar 7,47 $\mathrm{cm}^{2}$ dan B3 yaitu sebesar 7,40 $\mathrm{cm}^{2}$ (Table 3.). Kedua perlakuan menghasilkan luas kalus yang tidak berbeda setelah diuji statistik menggunakan ANOVA. Sedangkan perlakuan yang lain yaitu A1, A2, A3, dan B1 menunjukkan 
perbedaan yang signifikan dari perlakuan B2 dan B3. Hal ini menandakan bahwa perlakuan NAA dengan kisaran $3-5 \mathrm{mg} / \mathrm{L}$ yang dikombinasi dengan BAP dengan konsentrasi $0,5-1 \mathrm{mg} / \mathrm{L}$ memberikan pengaruh yang sama dalam menginduksi kalus dari kotiledon $G$. versteegii dan merupakan kombinasi ZPT yang terbaik dalam menginduksi pembentukan kalus pada eksplan kotiledon G. versteegii.

Kombinasi ZPT pada perlakuan B2 (3 $\mathrm{mg} / \mathrm{L}$ NAA $+0,5 \mathrm{mg} / \mathrm{L}$ BAP) merupakan kombinasi ZPT yang disarankan oleh Buddhapriya dan Senarath (2016) dan Munasinghe et al., (2017) untuk induksi kalus pada daun tanaman Gyrinops walla. Pada penelitian ini, waktu yang diperlukan untuk pembentukan kalus pertama lebih cepat dibandingkan kedua penelitian diatas. Keberhasilan induksi kalus dari koteiledon $G$. versteegii pada penelitian ini membuktikan bahwa kombinasi tersebut juga dapat diaplikasian pada spesies dan organ lain.

Tabel 3. Karakter morfologi kalus dari kotiledon Gyrinops versteegii pada berbagai kombinasi ZPT

\begin{tabular}{|c|c|c|c|}
\hline \multirow{2}{*}{ Pelakuan } & \multicolumn{2}{|c|}{ Morfologi kalus } & \multirow{2}{*}{$\begin{array}{l}\text { Luas Kalus } \\
\qquad\left(\mathrm{cm}^{3}\right)\end{array}$} \\
\hline & Struktur & Warna & \\
\hline $\mathrm{K}$ & - & - & - \\
\hline A1 & Kompak & Kecoklatan & $1.75 \pm 0.07^{\mathrm{d}}$ \\
\hline A2 & Remah & Putih & $6.52 \pm 0.11^{b}$ \\
\hline A3 & Remah & Krim & $6.62 \pm 0.11^{b}$ \\
\hline B1 & Remah & Putih & $5.44 \pm 0.10^{\mathrm{c}}$ \\
\hline B2 & Remah & Putih & $7.47 \pm 0.15^{\mathrm{a}}$ \\
\hline B3 & Remah & Putih & $7.40 \pm 0.18^{\mathrm{a}}$ \\
\hline
\end{tabular}

Ket : $\mathrm{A} 1=1 \mathrm{mg} / \mathrm{L} 2,4 \mathrm{D}+0.05 \mathrm{mg} / \mathrm{L} \mathrm{KIN}, \mathrm{A} 2=2$ $\mathrm{mg} / \mathrm{L} 2,4 \mathrm{D}+0.1 \mathrm{mg} / \mathrm{L} \mathrm{KIN}, \mathrm{A} 3=3 \mathrm{mg} / \mathrm{L} 2,4 \mathrm{D}+$ $0.15 \mathrm{mg} / \mathrm{L} \mathrm{KIN}, \mathrm{B} 1=1 \mathrm{mg} / \mathrm{L} \mathrm{NAA}+0.25 \mathrm{mg} / \mathrm{L} \mathrm{BAP}$, $\mathrm{B} 2=3 \mathrm{mg} / \mathrm{L} \mathrm{NAA}+0.5 \mathrm{mg} / \mathrm{L} \mathrm{BAP}, \mathrm{B} 3=5 \mathrm{mg} / \mathrm{L}$ $\mathrm{NAA}+1 \mathrm{mg} / \mathrm{L}$ BAP. Data menunjukkan rata-rata $+\mathrm{sd}$ dari 3 replikasi. Angka yang diikuti oleh huruf yang berbeda pada satu kolom menunjukkan berbeda nyata pada $\mathrm{p}<0.001$ dianalisis dengan ANOVA dan post hoc DMRT.

Kalus yang terbentuk dari eksplan kotiledon $G$. verstegii secara umum memiliki struktur yang friable atau remah, berair dan sangat mudah untuk dipisahkan. Tidak hanya itu, kalus juga memperlihatkan pertumbuhan yang sangat cepat dan menunjukkan karakter kalus embrionik.

Jin dan Keng (2013), menyatakan bahwa sifat friable pada struktur kalus disebabkan oleh sel-sel kalus yang tersusun longgar, dan berdinding tipis sehingga memiliki frekuensi pembelahan yang tinggi. Kalus bertekstur friable umumnya terbentuk akibat baiknya kemampuan jaringan dalam menyerap air (Akaneme dan Eneobong, 2008). Kotiledon sendiri merupakan bagian biji yang sangat mudah mengikat air untuk mempercepat perkecambahan. Karakter kotiledon ini sangat mendukung terbentuknya kalus friable.

Tekstur friable pada suatu kalus juga dipicu oleh keberadaan hormon auksin endogen yang diproduksi secara internal oleh eksplan. Kotiledon merupakan organ utama yang mendukung perkembangan embrio dan fase pertumbuhan awal tumbuhan. Kotiledon diketahui memiliki berbagai hormon endogen yang sangat kompleks untuk mendukung pemanjangan, proliferasi dan diferensiasi sel, seperti auksin (IAA), asam absisat dan sitokinin (Zeatin) (Centeno et al., 1997)

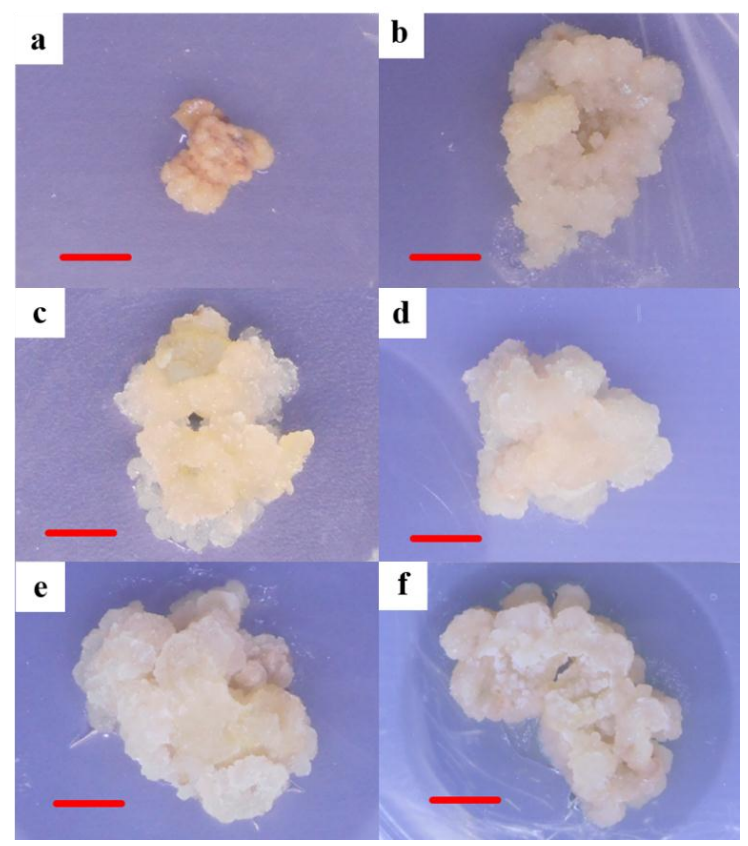

Gambar 2. Morfologi kalus dari kotiledon Gyrinops versteegii pada berbagai medium perlakuan. a) Perlakuan A1; b) Perlakuan A2; c) Perlakuan A3; d) Perlakuan B1; e) Perlakuan B2; dan f) Perlakuan B3. $\mathrm{Bar}=0,5 \mathrm{~cm}$

Pengamatan terhadap morfologi kalus juga menunjukkan bahwa kebanyakan kalus yang terbentuk pada eksplan memiliki warna yang cerah (Gambar 2.). Menurut $\mathrm{Na}$ et al. (2007), 
warna pada kalus erat kaitannya dengan ukuran ruang antar sel, sehingga semakin cerah warna kalus maka ukuran ruang antar selnya besar dan sel-selnya tervakuolasi. Shinta et al. (2020) juga menyatakan bahwa, warna kalus merupakan indikator morfologi yang digunakan untuk mengetahui pertumbuhan kalus dan mengetahui apakah kalus memiliki karakter embriogenik atau tidak. Kalus yang memiliki warna cerah seperti putih dan kekuningan diduga sedang mengalami masa pertumbuhan yang baik, sehingga warna yang dihasilkan pun berbeda namun dapat pula disebabkan oleh jaringan kalus yang tidak mengandung kloroplas. Tsuro et al. (1999) melaporkan bahwa umumnya kalus berwarna putih merupakan jaringan embriogenik yang belum mengandung kloroplas tetapi memiliki kandungan pati yang tinggi.

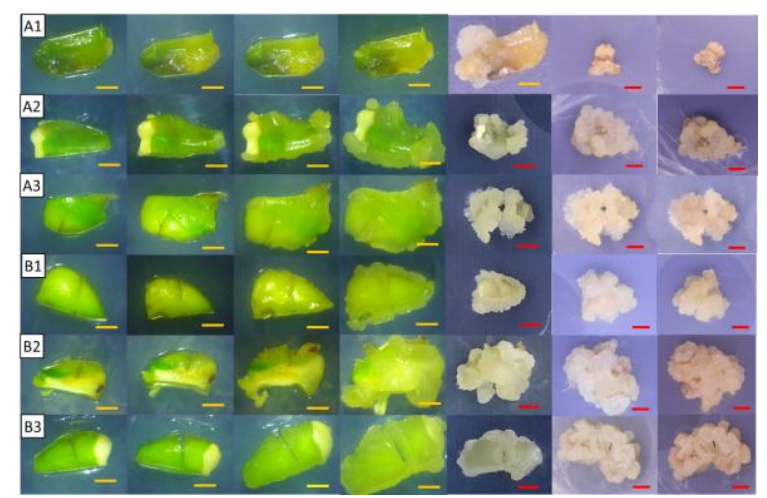

Gambar 3. Pertumbuhan kalus kotiledon Gyrinops versteegii pada berbagai medium perlakuan. $\mathrm{A} 1=1$ $\mathrm{mg} / \mathrm{L} \mathrm{2,4} \mathrm{D} \mathrm{+} \mathrm{0.05mg/L} \mathrm{KIN,} \mathrm{A2}=2 \mathrm{mg} / \mathrm{L} \mathrm{2,4} \mathrm{D} \mathrm{+}$ $0.1 \mathrm{mg} / \mathrm{L} \mathrm{KIN}, \mathrm{A} 3=3 \mathrm{mg} / \mathrm{L} 2,4 \mathrm{D}+0.15 \mathrm{mg} / \mathrm{L} \mathrm{KIN}$, $\mathrm{B} 1=1 \mathrm{mg} / \mathrm{L} \mathrm{NAA}+0.25 \mathrm{mg} / \mathrm{L} \mathrm{BAP}, \mathrm{B} 2=3 \mathrm{mg} / \mathrm{L}$ $\mathrm{NAA}+0.5 \mathrm{mg} / \mathrm{L} \mathrm{BAP}, \mathrm{B} 3=5 \mathrm{mg} / \mathrm{L} \mathrm{NAA}+1 \mathrm{mg} / \mathrm{L}$ BAP. Dari kiri ke kanan menunjukan waktu 0, 6, 9, 18, 24, 36, dan 42 hari setelah kultur. Bar kuning = $1 \mathrm{~mm}$, dan bar merah $=0,5 \mathrm{~cm}$

Pengamatan terhadap perubahan morfologi eksplan kotiledon hingga membentuk kalus (Gambar 3.), menunjukkan bahwa pertumbuhan kalus dari kotiledon $G$. versteegii mengalami 3 fase utama yaitu fase lag yang berlangsung hingga hari ke 6 untuk eksplan dalam medium A2, A3 dan B1, hari ke 9 untuk eksplan dalam medium B2 dan B3, serta hari ke 18 untuk eksplan dalam medium A1. Fase ini ditandai dengan terjadinya pembengkakan pada beberapa sisi eksplan. Selanjutnya, fase eksponensial diperkirakan terjadi hingga hari ke 36 pada semua perlakuan. Pada fase ini seluruh bagian eksplan perlahan-lahan berubah menjadi kalus sepenuhnya. Terakhir adalah awal fase penurunan atau kematian yang diamati pada hari ke 42. Fase ini ditandai dengan terjadinya perubahan warna pada eksplan menjadi kecoklatan (browning). Pada fase ini terjadi penurunan pertumbuhan akibat kematian sel. Saat berada dalam fase kematian, eksplan kemudian di subkultur ke medium baru untuk menghentikan fase kematian tersebut dan diperoleh kalus generasi berikutnya.

\section{Kesimpulan}

Hasil penelitian induksi kalus pada eksplan kotiledon $G$. versteegii menunjukkan bahwa perlakuan B2 dengan kombinasi $3 \mathrm{mg} / \mathrm{L}$ $\mathrm{NAA}+0.5 \mathrm{mg} / \mathrm{L}$ BAP dan B3 dengan kombinasi $5 \mathrm{mg} / \mathrm{L} \mathrm{NAA}+1 \mathrm{mg} / \mathrm{L}$ BAP merupakan perlakuan terbaik dalam menginduksi kalus pada kotiledon $G$. versteegii dengan menghasilkan ukuran luas kalus terbesar berturut-turut sebesar $7,47 \mathrm{~cm}^{2}$ dan $7,40 \mathrm{~cm}^{2}$. Perlakuan ini juga memberikan kalus yang friable dan embrionik.

\section{Ucapan terima kasih}

Terima kasih kepada Direktorat Riset dan Pengabdian Masyarakat Kemenrsitek-Dikti atas dukungan pendanaan melalui skema PDUPT No. 2726/UN1.DITLIT/DIT-LIT/PT/2020

\section{Referensi}

Aini, A. Q. (2015). Pengaruh Variasi Konsetrasi Hormon NAA Terhadap Induksi Kalus Gaharu (Gyrinops versteegii (Gilg) Domke) Melalui Teknik In Vitro dan Pemanfaatannya sebagai Karya Ilmiah Populer. Skripsi. Universitas Jember: Jawa Timur. https://repository.unej.ac.id/handle/12345 6789/67004

Akaneme, F.I., \& Eneobong, E.E. (2008). Tissue culture in Pinus caribaea Mor. var. Hondurensis barr. and golf. II: Effects of two auxins and two cytokinins on callus growth habits and subsequent organogenesis. African Journal of Biotechnology. 7, (6): 757-765. ISSN: 1684-5315. https://www.ajol.info/ 
index.php/ajb/article/view/58521

Benjamin, E. D., Ishaku, G. A., Peingurta, F. A., \& Afolabi, A.S. (2019). Callus Culture for the Production of Therapeutic. American Journal of Plant Biology. 4 (4): 76-84. doi: 10.11648/j.ajpb.20190404.14

Buddhapriya, A. N., \& Senarath, W.T.P.S.K. (2016). In vitro micropropagation of Gyrinops walla (gaerth) Using leaf disc explants. Proceedings of 1st International Conference on Bioscience and Biotechnology. 1: 11-14. doi: 10.17501/biotech.2016.1103

Centeno, M.L., Rodríguez, R., Berros, B., \& Rodríguez, A. (1997). Endogenous hormonal content and somatic embryogenic capacity of Corylus avellana L. cotyledons. Plant Cell. 17 (2): 139-144. doi: $10.1007 / \mathrm{s} 002990050367$

Efferth, T. (2019). Biotechnology Applications of Plant Callus Cultures. Engineering. 5: 50-59. doi: 10.1016/j.eng.2018.11.006

George, E. F., \& Sherrington, T. D. (1984). Plan Propagation by tissue culture handbook and directory of commercial laboratories. Eastern Press, England. ISBN: 0-95093250-7, $\quad$ pp: 477. https://www.journals.uchicago.edu/doi/ abs/1 0.1086/414482

Jin, C. S., \& Keng, C. L. (2013). Factor Affecting the Selection of Callus Cell Line and The Preparation of The Cell Suspension Culture of Artemisia annua L. Plant Tissue Cult \& Biotech. 23, (2): 157-16. doi: 10.3329/ptcb.v23i2.17507

Masita, R., Nuringtyas, T.R., Wijayanti, N., \& Hidayati, L. (2020). Antiviral activity of agarwood Aquilaria malaccensis lamk and Gyrinops versteegii (Gilg.) Domke leaves ethanolic extract against dengue serotype 3 virus in vitro. AIP Conference Proceedings 2231 (1): 040077. doi: $10.1063 / 5.0002645$

Munasinghe. S.P., Weerakoon, S. R., Somaratne,
S., \& Ranasinghe, C. (2017). An Efficient Callus Induction Protocol for Gyrinops walla Gaetner 'Walla patta', a commercially Important Agarwood Species in Sri Lanka. Scholars Journal of Research in Agriculture and Biology. 2 (2): 96-102. ISSN: 2456-6527. https://www.researchgate.net/ publication/326160208

Na, H., Kim, K.W., Kwack, Y., Kim, S.K., \& Chun, C. (2007). Comparative anatomy of embryogenic and non-embryogenic calli from Pimpinella brachycarpa. Journal of Plant Biology. 50 (3): 344-350. doi: 10.1007/BF03030665

Nuringtyas, T.R., Isromarina, R., Septia, Y., Hidayati, L., Wijayanti, N., \& Moeljopawiro, S. (2018). The antioxidant and cytotoxic activities of the chloroform extract of agarwood (Gyrinops versteegii (Gilg.) Domke) leaves on HeLa cell lines. AIP Conference Proceedings. 2002 (1): 020067. doi: 10.1063/1.5050163

Raza, G., Singh, M. B., \& Bhalla, P. L. (2019). Somatic Embryogenesis and Plant Regeneration from Commercial Soybean Cultivars. Plants (Basel, Switzerland). 9 (1): 38. doi. : 10.3390/plants9010038

Saikia, M., Shrivastava, K., Singh, S. S. (2013). Effect of Culture Media and Growth Hormones on Callus Induction in Aquilaria malaccensis Lam., a Medically and Commercially Important Tree Species of North East India. Asian Journal of Biological Sciences. 6 (2): 96-105. doi: 10.3923/ajbs.2013.96.105

Sari, Y.P., Kusumawati, E., Saleh, C., Kustiawan, W., \& Sukartingsih. (2018). Effect of sucrose and plant growth regulators on callogenesis and preliminary secondary metabolic of different explant Myrmecodia tuberosa. Nusantara Bioscience. 10 (3): 183-192. doi: 10.13057/nusbiosci/n100309

Shinta. S., Minarno,E.B., \& Rofiqoh, I. (2020). In vitro embryogenic callus induction of 
Carica pubescens Lenne and K.Koch using 2,4-D (2,4-Dichlorophenoxy Acetic Acid) and BAP (6Benzylaminopurin). Journal of biology researcher. 25, (2) : 3844.

Retrieved: http://www.berkalahayati.org/index.php/j urnal/article/view/49

Susilo A, Kalima T, \& Santoso E. (2014). Panduan Lapangan Pengenalan Jenis Pohon Penghasil Agarwood Gyrinops spp. di Indonesia. Puslitbang - Konservasi dan Rehabilitasi. Kementrian Kehutanan Indonesia. http://lib.ugm.ac.id/ind/

Trimulyaningsih. (2014). Ekologi agarwood Gyrinops versteegii (Gilg.) Domke di hutan Lombok Barat. Disertasi. Universitas Gadjah Mada: Yogyakarta. http://lib.ugm.ac.id/ind/

Tsuro, M., Koda, M., \& Inoue, M. (1999). Comparation effect of different types of cytocine for shoot formation and plant regeneration in leaf-derived callus of lavender (Lavandura vera DC). Scientia Horticulturae, 81 (3): 331-336. doi: $10.1016 / \mathrm{S} 0304-4238(99) 00003-5$

Wardana, T.A.P., Nuringtyas, T.R., Wijayanti, N., \& Hidayati, L. (2019). Phytochemical analysis of agarwood (Gyrinops versteegii (Gilg.) Domke) leaves extracts as anticancer using GC-MS. AIP Conference Proceedings. 2194 (1): 020136. doi: $10.1063 / 1.5139868$ 